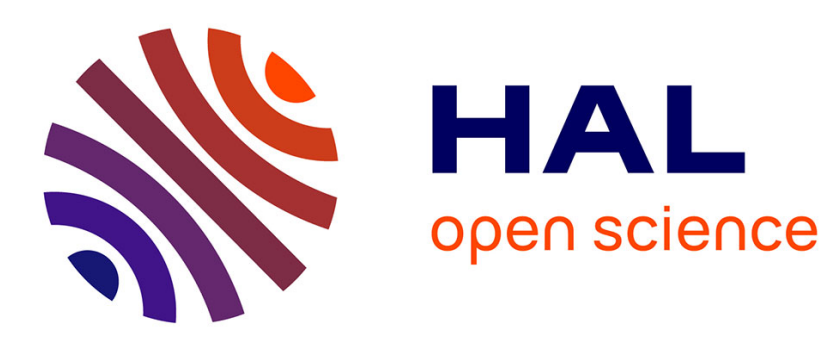

\title{
Impacts of health and economic costs on street children working as waste collectors in Dhaka City
}

\author{
Md. Mahmudul Alam, Mohammad Saeed Hossain, Nurul Islam, Md Wahid
}

Murad, Niaz Ahmed Khan

\section{- To cite this version:}

Md. Mahmudul Alam, Mohammad Saeed Hossain, Nurul Islam, Md Wahid Murad, Niaz Ahmed Khan. Impacts of health and economic costs on street children working as waste collectors in Dhaka City. International Journal of Environment and Sustainable Development, 2021, 20 (1), pp.29-50. 10.1504/IJESD.2021.112666 . hal-03520146

\section{HAL Id: hal-03520146 \\ https://hal.science/hal-03520146}

Submitted on 10 Jan 2022

HAL is a multi-disciplinary open access archive for the deposit and dissemination of scientific research documents, whether they are published or not. The documents may come from teaching and research institutions in France or abroad, or from public or private research centers.
L'archive ouverte pluridisciplinaire HAL, est destinée au dépôt et à la diffusion de documents scientifiques de niveau recherche, publiés ou non, émanant des établissements d'enseignement et de recherche français ou étrangers, des laboratoires publics ou privés. 


\title{
Impacts of Health and Economic Costs on Street Children Working as Waste Collectors in Dhaka City
}

\author{
Md. Mahmudul Alam* \\ School of Economics, Finance \& Banking \\ Universiti Utara Malaysia \\ 06010UUM Sintok, Kedah, Malaysia \\ Email: rony000@gmail.com \\ Mohammad Saeed Hossain \\ Department of Economics \\ East West University \\ A/2, Jahurul Islam Avenue, \\ Jahurul Islam City, Aftabnagar, \\ Dhaka-1212, Bangladesh \\ Email: saeedhossainbd@gmail.com \\ Nurul Islam \\ Delta Medical College \& Hospital \\ 26/2, Principal Abul Kashem Road, Mirpur-1, \\ Dhaka-1216, Bangladesh \\ E-mail: nislam105@gmail.com
}

Md Wahid Murad

UniSA College

University of South Australia

Adelaide, SA 5001, Australia

E-mail: wahid.murad@unisa.edu.au

Niaz Ahmed Khan

Department of Development Studies

University of Dhaka

Dhaka- 1205, Bangladesh

Email: niaz.khan@yahoo.com

* Corresponding author

\section{Citation Reference:}

Alam, M.M., Hossain, M.S., Islam, N., Murad, M.W. \& Khan, N.A. (2021). Impacts of Health and Economic Costs on Street Child Waste Collectors in Dhaka City. International Journal of Environment and Sustainable Development, 20(1), 29-50. (online) https://dx.doi.org/10.1504/IJESD.2021.112666 


\title{
Impacts of Health and Economic Costs on Street Children Working as Waste Collectors in Dhaka City
}

\begin{abstract}
This research investigates the health impacts and access to health services by children who are engaged in waste collection in Dhaka, the capital city of Bangladesh. The relevant qualitative data were collected through expert interviews and personal observations, while quantitative data were gathered through a face-to-face questionnaire survey given to 50 street children who collected waste at the landfill site located in Dhaka city's Matuail area. The results indicate that $94 \%$ of these children have suffered from many health problems, such as fever and fatigue due to tiredness, dizziness, and vomiting. Consequently, a significant portion of their daily income is spent on medical treatment. This study suggests that the waste collection system must integrate modern technological, health and environmental resources so that: firstly, they do not harm waste collectors; and secondly, rehabilitate the street children and give them better access to acceptable basic amenities. This is a priority the city authorities.
\end{abstract}

Key Words: Street Children; Landfill; Waste collection; Waste management; Health services; Health cost; Dhaka City

\section{Introduction}

It is now well established that street children constitute one of the most vulnerable and disadvantaged segments of the population throughout the developing world, and Bangladesh is no exception. Street children generally come from the families that are poor and socioeconomically vulnerable. Families do not have a good level of earnings so that they can eat properly or have good meals consistently; as a result, the majority of street children suffer from malnutrition-related diseases (Islam, 2013). A large-scale International Labour Organization (ILO) sponsored survey undertaken in the Philippines in 1995 found that $60 \%$ of all economically active children were exposed to hazardous working conditions. Moreover, 19\% were exposed to biological hazards, $26 \%$ were exposed to chemical hazards and $51 \%$ were exposed to environmental hazards (NSOP, 1998). Out of all child workers, $24 \%$ suffered workrelated illness and/or injury, i.e. the prevalent rate was much higher than that for adult workers. The most common injuries were cuts, wounds, or skin punctures, and they accounted for $69 \%$ of the total injuries. Body aches and pains (59\%) and skin diseases (22\%) were the most common work-related illnesses.

While the majority child workers are prone to immediate health problems, they are also likely to develop numerous diseases that might only manifest in adulthood due to these early life exposures (Kassebaum et al., 2017). It has been previously documented that exposure to pesticides, chemicals, dusts, and carcinogenic agents in agriculture, mining and quarrying and manufacturing increases the risks of developing bronchial complaints, cancers and a wide variety of diseases (ILO, 1998; Fassa et al., 2000; Goel et al., 2012). In India, large numbers of child labourers who work in industries suffered from high rates of tuberculosis (TB) and silicosis; stonecutters and slate workers, for example, have silicosis rates of $35 \%$ and $55 \%$, respectively (Parker, 1997; Ravindra et al., 2016). A report published by the ILO (ILO, 1998) indicates that cancer risks have risen significantly through exposure to asbestos in mining and construction and to aniline dyes in carpet and garment manufacturing. An epidemiological study on child labour in Egypt reveals that children are at risk of developing chronic health problems directly associated with particular exposure. However, secondarily these exposures 
may also enhance some biological events that decrease the latency period of some lifethreatening diseases (Mohammed et al., 2014).

Landfill areas are closely linked to health issues. Hossain (2016) contended that children working in landfills needed better medical facilities. Abdou et al. (2007) identified four main health problems, these being respiratory or allergic infections, eye infections, gastrointestinal tract (GIT) infection and musculo-skeletal injuries. These are conditions that accounted for $65.5 \%, 48.3 \%, 20.7 \%$ and $17.2 \%$, respectively, of the landfill workers in Jeddah, Saudi Arabia.

Research specific to waste incinerators has provided mixed evidence on the effects of proximity to incinerators on health (Reeve et al., 2013). The study by Rushton (2003) claimed there was not much evidence that proximity to incinerators was associated with reproductive or developmental effects. Cancer incidence and mortality in populations around landfill sites or incarcerators were equivocal, and inconsistent findings were reported. Some geographical comparison studies investigated cancer mortality and incidence around waste sites (Wang et al., 2016; Edelstein, 2018). They did not find any differences in cancer incidence around the waste disposal area when compared with distant sites. In contrast, recent studies confirm that the increased frequency of different cancer types such as ovarian, gastrointestinal, oesophageal, stomach, colon and rectal cancer was related the areas around waste disposal zones and toxic release inventory sites (Choi et al., 2006; Roberts, 2017; Hanchette et al., 2018).

There is generally a high level of awareness in the health sector regarding the problems connected with harmful healthcare waste, and that is mostly due to the potential spread of HIV from poor waste dumping (Mukankomeje, 2010). Improper waste disposed on land or in water typically occurs in some developing countries and especially among less or poorly educated people. Toxic and infectious materials are dangerous to human health. These infectious materials can cause skin and blood infections, eye and respiratory infections as well as different diseases caused from vector-borne germs. Uninhibited burning of waste at dump sites releases fine particles into the air, which are the main reason for eye and respiratory illness. Mosquitoes grow in waste materials, which results in spreading disease and particularly malaria and dengue fever. Rats find safe haven and food in waste dumps. Rats consume and spoil food, spread disease, and inflict unpleasant bites (Sridevi, 2012). Poor hygiene practices of waste pickers contribute to their health vulnerabilities, especially carrying worm infestations and suffering respiratory and other infections (Singh \& Chokhandre, 2015).

Infections in children can take place from direct contact with contaminated materials, dog and rodent bites, or eating of waste-fed animals. Wounds can lead to tetanus, hepatitis, and HIV infection. Injuries at dumps are caused by surface substances, underground fires and slides of land or materials. Headaches and nausea are very evident among children because of the anoxic conditions at the disposal sites where they work. These places have high methane, carbon dioxide, and carbon monoxide concentrations, and lead poisoning can wreak havoc among children when materials with lead-containing batteries, paints, and solders are being burnt (Cointreau, 2006). A review of the literature shows that socio-demographic differences of populations living near waste sites may also confound results. Finally, there are relationships between occupational external radiation exposure and cancer risks (Haylock et al., 2018).

According to Aweng (2014), garbage collectors with a middle-income level have suffered the most from cough and fever because they were not able to visit a specialist for their health checkup. Neither did they have the opportunity to have good nutrition for a better immune system since they earned money that was only sufficient to support their livelihood (Aweng, 2014). 
Amegah and Jaakkola (2016) observed that tuberculosis, bronchitis, asthma, pneumonia, dysentery, parasites, and malnutrition were generally the most experienced diseases among waste pickers, and the report is based on the health studies of waste pickers conducted in Bangalore, Manohar, and New Delhi in India. Another study undertaken by the Direct Initiative for Social \& Health Action (1996) was done on 180 waste pickers working at the Calcutta, India open dumps in 1995. During the course of one year, $40 \%$ of waste pickers had chronic cough, and $37 \%$ contracted jaundice. The average incidence of diarrhoea was $85 \%$, fever was $72 \%$, and coughs and colds were $63 \%$. Eye soreness or redness occurred in $15 \%$ and skin ulcers in $29 \%$, and the report relates that nearly all rates were higher at the largest dump site than the average.

Ray et al. (2004) conducted a study which assessed the respiratory and general health of rag pickers who rummage through the garbage dumps and landfill sites in India. They found respiratory symptoms and lung function decrement were recorded in $94 \%$ and $52 \%$ of the rag pickers, respectively, compared with $56 \%$ and $34 \%$ of the control samples. Using a mixedmethods approach, Schenck et al. (2019) explored the health risks to which waste pickers working on nine different landfills in South Africa were exposed. A socio-ecological framework served to analyse and present the results which indicate that waste picking, by its very nature, lends itself to innumerable health risks. However, in their systematic review of 379 papers from 1995-2014, Ncube et al. (2017) examined the health risks posed by municipal solid waste management activities, concluding that overall epidemiological evidence in reviewed articles is inadequate. This is mainly due to methodological limitations and future research needs to develop tools able to demonstrate causal or non-causal relationships between specific waste management operations and adverse health endpoints.

Fire in the dumping area is the cause of some respiratory diseases experienced by pickers, and the risk could be reduced by using proactive masks (Cowing, 2013). The findings of the study by Dias (2016) reveal that waste pickers strongly believe they contribute to the environment regarding public health issues by reducing pollution and maintaining city cleanliness. Another frequently mentioned contribution is related to employment. Saifullah (2016) observed that some child labourers worked in Dhaka and elsewhere in Bangladesh. Environmental awareness among the street pickers is necessary. The battery recycling industry in Dhaka employs some child labourers, and this has a lasting impact on their health.

Children are particularly vulnerable to toxins because they ingest more water, food, and air per unit of body weight; their metabolic pathways are less developed in the ability to detoxify and excrete toxins. In addition, any disruption during their growth years can easily disrupt development of their organs, nerves, immunity, endocrine, and reproductive systems (Posso, 2019). Castro and Hunting (2013) found that children suffered joint injuries due to lifting heavy waste-filled containers and respiratory illness from ingesting particulates, bio-aerosols, and volatile organics during waste collection, and from working in smoky and dusty conditions at open dumps. Added to this, the likelihood of child labourers suffering poor health in their adulthood is a very plausible factor. When a child works because of poverty, he or she lacks essential resources like food and basic healthcare; consequently, chronic under-nourishment in childhood will affect a person's life trajectory and expected to have a long-run constructive impact on the individual's health practices (Guarcello, 2004).

Understanding the physical health background in the context of behaviour and other socioeconomic features of the environment in which children live and work, is necessary for establishing the appropriate measures that policy-makers should make. Ultimately, the actions 
undertaken and based on comprehensive data can ensure children labourers' rights and strategies to eradicate poverty from society. The aim of this study is to understand the physical health impacts of street children who work as waste collectors in Dhaka, Bangladesh. Understanding these street children's health issues due to their exposure to various forms of waste in one of the most crowded cities in the world, will help to develop an effective policy globally for similar situations.

\section{Methodology}

This study employed two different methodologies: firstly, the quantitative study was done on the basis of a carefully designed semi-structured questionnaire; secondly, this was actually done following the qualitative study. The qualitative study comprised a survey that was conducted among two different types of respondents: (i) paediatricians (child specialists); and (ii) children living in the studied geographical location. Some informal observation was also done to understand the different issues within the surveyed location and gauge the lifestyles of the waste collecting-children living in this location. Desk research was conducted to design the discussion guide for the qualitative survey, which includes searching for information online, relevant journal articles, monographs, book chapters, etc.

The interviews with experts in the current study involved two paediatricians, who have worked for more than five years at the study location. These interviews helped to generate ideas on the types of patients who visited the doctors, type of diseases, the reason for these diseases, and prevention of the diseases. Before finalising the questionnaire, a pilot survey on five in-depth interviews was conducted among the street children - the waste collectors staying within the study location which was the landfill located at Matuail, Dhaka. Finally, the data were collected through a questionnaire and the samples were selected based on convenient random sampling. Data were collected between September and November 2013. The final survey included data gathered from 50 children waste collectors at the landfill in Matuail, Dhaka. The inclusion criteria were: permanent and/or temporary waste collectors and working for at least 6 months or more. In total 74 street children who collect waste fulfilled the eligibility criteria and 50 participated in this study (response rate of 67\%).

\section{Findings \& Discussions}

\subsection{Demographic and Economic Profile of Street Waste Collector Children}

The study conducted a survey among 50 respondents and of these, $40 \%$ were girls and $60 \%$ were boys. The age of respondents ranged from 8-15 years (Appendix 1). 98\% of responders went to school while the other $2 \%$ did not. Among the $98 \%$ school-going children, $62 \%$ went to non-government organization (NGO) schools and 36\% attended government primary schools. Those who went to NGO schools were provided with food and education materials by the NGO. Children who responded said they started collecting waste at the age of 6 and had worked for 2.12 years. $40 \%$ of girls and $16.6 \%$ of boys collected food from waste items. $64 \%$ of responders lived in tin shed houses while $22 \%$ lived in a house made of bamboo and other materials; $14 \%$ responders lived in brick-built houses. Those who were tenants paid an average monthly rent of 2,213 Bangladesh Taka (Bangladesh currency).

The range of earnings for the girls was 40 to 119 Bangladesh Taka while for the boys it was 40 to 150 Bangladesh Taka. The overall average income of children was 78.70 Bangladesh Taka per day. Half of the responders live in a family with four members. Among the responders, 20 
families had 3 members earning money and 17 families had 4 members earning a livelihood. The family's income made by waste collection varied from 70 to 800 Bangladesh Taka per day. From other sources, the income range varied from 500 to 550 Bangladesh Taka per day. For a family of 4.16 members, the average family income was 573.8 Bangladesh Taka. $16 \%$ of waste collector children lived below the poverty line (income of 1.25 USD per day on the margins of the poverty level). The majority of children lived in vulnerable situations because they saved nothing for emergency situations, and basically were unable to continue working or pay for immediate healthcare costs, etc.

\subsection{Health Problems and Waste Collection}

Out of 50 responders, 7 girls and 13 boys claimed their health was poor (Table 1). At the same time, 8 girls and 11 boys felt they had very poor health compared to others; 4 girls and 5 boys felt fair compared to his /her peers; and 1 girl and 1 boy felt they were in excellent health compared to others.

Table 1: Respondents' present health condition

\begin{tabular}{lcclc}
\hline Gender & Poor & Very poor & Fair & Excellent \\
\hline Girl & $7(14 \%)$ & $8(16 \%)$ & $4(8 \%)$ & $1(2 \%)$ \\
Boy & $13(26 \%)$ & $11(22 \%)$ & $5(10 \%)$ & $1(2 \%)$ \\
\hline Grand Total & $20(40 \%)$ & $19(38 \%)$ & $9(18 \%)$ & $2(4 \%)$ \\
\hline
\end{tabular}

The most important issue for the waste collector children was the risk to their health, something that $94 \%$ of the children agreed to. The average scale was 4.4 out of 5 for the health risk (Table 2 ). The average value of the scale was 4.50 , and $88 \%$ children agreed that impacts on their health due to their work harmed what they did in the future. Waste was the main reason for chronic diseases, and this point of view was agreed to by $86 \%$ of responders, and the average value of the scale was 4.44 . When the children were asked how to get rid of a health risk, $70 \%$ answered that they had no idea; on the other hand, $22 \%$ stated they would look for hospital treatment.

Table 2: Respondents' perceptions of health impacts of waste collection

\begin{tabular}{|c|c|c|c|c|c|c|c|c|c|}
\hline \multirow{2}{*}{$\begin{array}{l}\text { Assessment of personal } \\
\text { ability }\end{array}$} & \multicolumn{5}{|c|}{ Observation Scale } & \multirow{2}{*}{$\begin{array}{l}\text { Average } \\
\text { Value } \\
\text { of Scale }\end{array}$} & \multirow{2}{*}{ S.D. } & \multirow{2}{*}{$\begin{array}{c}\text { Agreed } \\
(4 \& 5) \\
\text { Observations } \\
\end{array}$} & \multirow{2}{*}{$\begin{array}{c}\text { Disagreed } \\
(1 \& 2) \\
\text { Observations } \\
\end{array}$} \\
\hline & 1 & 2 & 3 & 4 & 5 & & & & \\
\hline $\begin{array}{l}\text { Health risk is the main } \\
\text { issue for children }\end{array}$ & $0 \%$ & $2 \%$ & $4 \%$ & $22 \%$ & $72 \%$ & 4.44 & 0.67 & $94 \%$ & $2 \%$ \\
\hline $\begin{array}{l}\text { Health impact destroys } \\
\text { a career in the future }\end{array}$ & $0 \%$ & $6 \%$ & $6 \%$ & $20 \%$ & $68 \%$ & 4.5 & 0.86 & $88 \%$ & $6 \%$ \\
\hline $\begin{array}{l}\text { Waste is the main } \\
\text { reason for chronic } \\
\text { disease }\end{array}$ & $0 \%$ & $0 \%$ & $14 \%$ & $28 \%$ & $58 \%$ & 4.44 & 0.73 & $86 \%$ & $0 \%$ \\
\hline $\begin{array}{l}\text { Children know how to } \\
\text { protect their health } \\
\text { from risk }\end{array}$ & $28 \%$ & $42 \%$ & $8 \%$ & $10 \%$ & $12 \%$ & 2.36 & 1.32 & $22 \%$ & $70 \%$ \\
\hline
\end{tabular}

There were $36 \%$ children who had some bad habits, and this was opined by 50 respondent children (Table 3). Our findings also showed that $2 \%$ children smoked cigarettes, $8 \%$ took betelleaf, and $6 \%$ took tobacco with betel-leaf. They had been doing this for more than 1 year. 
However, $84 \%$ children agreed that bad habits were more harmful than waste collecting. At the same time, $6 \%$ disagreed and $6 \%$ of children realised the impacts of bad habits on their working lives.

Table 3: Respondents' addiction in tobacco with betel-leaf

\begin{tabular}{lcccc}
\hline Gender & No bad habits & Cigarettes & Betel-leaf & $\begin{array}{c}\text { Tobacco with } \\
\text { Betel-leaf }\end{array}$ \\
\hline Girl & $16(32 \%)$ & $1(2 \%)$ & $2(4 \%)$ & $1(2 \%)$ \\
Boy & $23(46 \%)$ & $10(20 \%)$ & $2(4 \%)$ & $2(4 \%)$ \\
\hline Grand Total & $32(64 \%)$ & $11(22 \%)$ & $4(8 \%)$ & $3(6 \%)$ \\
\hline
\end{tabular}

\subsection{Types of Health Problems Suffered by Street Waste Collector Children}

\section{i. General Health Problems}

Waste collecting children faced various health problems, like fever, fatigue or exertion intolerance due to tiredness, dizziness, and vomiting, etc. Based on the records for the last six months, $64 \%$ of respondents suffered from fever whereas $54 \%$ of cases were chronic in nature. Their average days of suffering numbered 43.59;31.25\% of children received treatment (Appendix 2). 68\% children felt tired due to their exertions and of these, $60 \%$ were chronically tired. Their average days during which they suffered health problems was 25.88 ; average treatment was received by $17.65 \% .86 \%$ of children were victims of dizziness and among $64 \%$ of them this was chronic. Their average days of suffering numbered 22.59 and average treatment was received by $9.30 \%$.

\section{ii. Growth and Developmental Problems}

Out of all 50 children, $64 \%$ suffered from growth retardation and $18 \%$ of them received treatment. $68 \%$ of all 50 children suffered from developmental/mental retardation, and $23.53 \%$ (34 children) received treatment.

\section{iii. Musculo-skeletal Problems}

Sometimes, waste collecting children were affected by musculo-skeletal problems, such as arthritis (joint pain) and back pain. Results show that $14 \%$ of children were affected by joint pain and it was chronic among $12 \%$ of them. Their average days of suffering numbered 17.43; average treatment was received by $85.71 \%$ (Appendix 2). $30 \%$ of the children suffered from back pain and $20 \%$ were chronic patients. Their average days of suffering were 15.26 , and $73.33 \%$ children received treatment. $2 \%$ of the children had bone fractures and their average suffering days numbered 90 . In fact, all $100 \%$ of the children received treatment.

\section{iv. Dermatological Manifestation (Skin Problems)}

Street children are affected by many types of dermatological manifestations (skin problems). In the case of skin health impact on the street children, the survey results show that $12 \%$ children suffered from a skin rash problem and this was chronic among 6\% of them. Among these affected children, their average days of suffering numbered 28.33 days; the average treatment was received by $66.66 \%$ of children (Appendix 2). For the $2 \%$ children who were chronically affected by rash and irritation problems, their average days of suffering was 15 ; average treatment was received by $16.66 \%$. Among the $52 \%$ children who endured a scabies problem, 
$36 \%$ were chronic sufferers. Their average days of suffering numbered 24.57 days and average treatment was received by $23.07 \%$ of children. $50 \%$ of the children suffered from cut injuries, and their average days of suffering were 13.32. Average treatment was received by $96 \%$ children, and for $6 \%$ of the children who were affected by bruises, their average days of suffering were 20 . Treatment was received by $100 \%$ of affected children.

\section{v. Respiratory Problems}

The results show that among the respiratory problems, there were coughs and haemoptysis (coughing with blood) or dyspnoea (shortness of breath). According to the survey results, $68 \%$ of children suffered with a cough problem. Among $60 \%$ of chronic sufferers of this group, their average days of suffering were 17.29 ; average treatment was received by $82.35 \%$. Furthermore, $2 \%$ of the children suffered from coughing with blood; their average day of suffering was 20 days, and average treatment was received by $100 \%$. Out of the children who suffered from shortness of breath, $14 \%$ children were chronic sufferers.

\section{vi. Gastrointestinal Trace Problems}

According to the survey results, $36 \%$ of children were affected by a gastrointestinal tract problem. Among the $30 \%$ of chronic sufferers, their average days of suffer were 16.05 days; average treatment was received by $94.44 \%$ (Appendix 2). Out of the $10 \%$ children who suffered diarrhoea, $8 \%$ of children were chronic sufferers. Their average days of suffer numbered 32 and average treatment was received by $80 \%$. Children sometimes vomited because they worked in unhealthy environments. $30 \%$ children were affected by vomiting and of these, $24 \%$ were chronic sufferers. On average their days of suffering were 30.26 , and average treatment was received by $13.33 \%$.

\section{vii. Vision \& Dental Problems}

The survey results show that $6 \%$ of children were affected by eye vision problems; among them, $2 \%$ were chronic sufferers, and the average days of suffering were 18.33 ; on average treatment was received by $66.66 \%$ (Appendix 2). $16 \%$ of the children were affected by dental problems and it emerged that $8 \%$ were chronic sufferers, and their average days of suffering were 14.5 days.

\section{viii. Wild Animal Hazards}

Mosquitoes, flies, and various insects lived and bred in the landfill area. Moreover, children were affected on several occasions by parasites and head lice. Added to this, children were affected by stray animals like dogs, and their average days of suffering were 19.75 days; average treatment was received by $100 \%$ (Appendix 2). As the survey results show, $4 \%$ of children were affected by the parasites, and average treatment was received by $100 \%$ of children. $2 \%$ of children were affected by head lice problem and they were chronic sufferers. Their average days of suffering were 40 days, and average treatment was received by $100 \%$. Meanwhile $8 \%$ of children were affected by mice/rats; their average days of suffering amounted to 4.75 days, and average treatment was received by $8 \%$. 


\subsection{Currently Available Health Service Facilities}

$30 \%$ of the children agreed that they received help from health facilities (Table 4). However, $64 \%$ opined that they did not get any assistance from such facilities. The average scale was 2.46. $2 \%$ of the children agreed that health services were not expensive but $94 \%$ agreed that it was expensive, and an average scale was 4.52 .

Table 4: Respondents' access to health facilities

\begin{tabular}{|c|c|c|c|c|c|c|c|c|c|}
\hline \multirow{2}{*}{$\begin{array}{l}\text { Assessment of personal } \\
\text { ability }\end{array}$} & \multicolumn{5}{|c|}{ Observation Scale } & \multirow{2}{*}{$\begin{array}{l}\text { Averag } \\
\text { e Value } \\
\text { of Scale }\end{array}$} & \multirow{2}{*}{ S.D } & \multirow{2}{*}{$\begin{array}{c}\text { Agreed } \\
(4 \& 5) \\
\text { Observation } \\
\text { s }\end{array}$} & \multirow{2}{*}{$\begin{array}{c}\text { Disagreed } \\
(1 \& 2) \\
\text { Observation } \\
\mathrm{s} \\
\end{array}$} \\
\hline & 1 & 2 & 3 & 4 & 5 & & & & \\
\hline $\begin{array}{l}\text { Street children going to } \\
\text { health facilities }\end{array}$ & $\begin{array}{l}34 \\
\%\end{array}$ & $\begin{array}{l}30 \\
\%\end{array}$ & $\begin{array}{l}6 \\
\%\end{array}$ & $\begin{array}{l}16 \\
\%\end{array}$ & $\begin{array}{l}14 \\
\%\end{array}$ & 2.46 & 1.46 & $30 \%$ & $64 \%$ \\
\hline $\begin{array}{l}\text { Medical service is too } \\
\text { expensive }\end{array}$ & $0 \%$ & $2 \%$ & $\begin{array}{l}4 \\
\%\end{array}$ & $\begin{array}{l}34 \\
\%\end{array}$ & $\begin{array}{l}60 \\
\%\end{array}$ & 4.52 & 0.68 & $94 \%$ & $2 \%$ \\
\hline
\end{tabular}

$66 \%$ of children believed they could not consult a doctor because they could not afford to. Out of those children, $30 \%$ were girls and $36 \%$ were boys. $34 \%$ of the children thought that poverty was the main cause, which discouraged them from getting health treatment; out of them, 10\% were girls and $24 \%$ were boys.

Children who collected waste could get health treatment in various ways, and data in Table 5 show that among the respondents, 4 girls and 2 boys did not receive any health service from anybody. Among the 30 respondents, 11 girls and 19 boys were able to get health services from the NGOs, pharmacy, community hospital, health centre and government hospital. Among the 14 respondents, 5 girls and 9 boys received health services from various organisations.

Table 5: Respondents' sources of receiving health treatment

\begin{tabular}{lccc}
\hline & \multicolumn{2}{c}{ Gender } & \\
\cline { 2 - 3 } Health service & Girl & Boy & Total \\
\hline No service & $4(8 \%)$ & $2(4 \%)$ & $6(12 \%)$ \\
\hline Single Service & & & \\
NGO & $1(2 \%)$ & $2(4 \%)$ & $3(6 \%)$ \\
Pharmacy & $7(14 \%)$ & $13(26 \%)$ & $20(40 \%)$ \\
Community hospital & $1(2 \%)$ & $0(0 \%)$ & $1(2 \%)$ \\
Health centre & $1(2 \%)$ & $1(2 \%)$ & $2(4 \%)$ \\
Government hospital & $1(2 \%)$ & $0(0 \%)$ & $1(2 \%)$ \\
Free medical camp & $0(0 \%)$ & $1(2 \%)$ & $1(2 \%)$ \\
Private hospital & $0(0 \%)$ & $2(4 \%)$ & $2(4 \%)$ \\
Total & $11(22 \%)$ & $19(38 \%)$ & $30(60 \%)$ \\
\hline Multiple Service & & & \\
Government hospital, Pharmacy & $2(4 \%)$ & $3(6 \%)$ & $5(10 \%)$ \\
Free camp, Pharmacy & $2(4 \%)$ & $1(2 \%)$ & $3(6 \%)$ \\
NGO, Pharmacy & $1(2 \%)$ & $2(4 \%)$ & $3(6 \%)$ \\
NGO, Private hospital & $0(0 \%)$ & $1(2 \%)$ & $1(2 \%)$ \\
NGO, Health officers & $0(0 \%)$ & $2(4 \%)$ & $2(4 \%)$
\end{tabular}




\begin{tabular}{lccc} 
Total & $5(10 \%)$ & $9(18 \%)$ & $14(28 \%)$ \\
\hline Grand Total & $20(40 \%)$ & $30(60 \%)$ & $50(100 \%)$ \\
\hline
\end{tabular}

In every case, waste collecting children received few medicines or medical services. Consequently, these children experienced general health problems, like fever, fatigue or exertion intolerance due to tiredness, dizziness, and vomiting, etc. Only $34.38 \%$ received a free healthcare service, and $15.62 \%$ received free medicine (Appendix 3). For fatigue or exertion intolerance due to problems connected with tiredness, $17.65 \%$ got free physician advice, and $8.82 \%$ received free medicine. None received free medicine for dizziness but $6.98 \%$ could consult a doctor. For the problem of vomiting, they received no medicine or doctor service. For the growth retardation problem, $15.62 \%$ of children received free physician service, and $9.37 \%$ could obtain free medicine. For the developmental/mental retardation problem, $20.59 \%$ of children were treated free by a doctor, and $8.82 \%$ received free medical service. For pain of the joints, $14.28 \%$ of children received free physician service but none managed to get free medicine. For back pain problems, $53.33 \%$ of children received free doctor service, and $20 \%$ received medicine. For bone fractures, no child received any free surgery or medicine. For the skin rash problem, $33.33 \%$ and $16.66 \%$ of children received free general practitioner and medicine, respectively.

All of children who were affected by dermatitis (hot $\&$ irritated skin) consulted a physician. For the scabies problem, $53.85 \%$ could consult a doctor and $15.38 \%$ received a free medicine service. None received any free treatment for bruises. Regarding cough-related problems, $26.47 \%$ and $32.35 \%$ received free doctor and medicine, respectively. For coughing with blood and shortness of breath, no free medicine service was served. $22.22 \%$ of children could consult a doctor if they had abdominal pain. There was no free health service for diarrhoea. For eye vision-related problems, $33.33 \%$ of children received free assistance from a doctor, but they did not receive any free medicine. For dental problems, there was no free healthcare service. 100\% of children were affected by stray animal attacks, and all of them received a free medical service. If they had been attacked by mice/rats, $25 \%$ of the children could consult a doctor, but they did not get any free medicine.

\subsection{Economic Cost of Health Problems of Street Waste Collector Children}

\section{i. General Health Problems}

For general health problems, like fever, fatigue or exertion intolerance due to tiredness, dizziness, and vomiting, etc., the average expenditure was 51.71 Bangladesh Taka, and the opportunity cost was 305.94 Bangladesh Taka (Appendix 3). For fatigue or exertion intolerance due to tiredness, the average expenditure per child was 24.26 Bangladesh Taka, and the opportunity cost was 177.50 Bangladesh Taka per child. For dizziness, 23.12 Bangladesh Taka was the average expenditure, and opportunity cost was 99.65 Bangladesh Taka.

\section{ii. Growth and Developmental Problems}

For the growth retardation problem, the average expenditure was 33.75 Bangladesh Taka, and due to absence from work, 227.65 Bangladesh Taka could not be earned by them (Appendix 3). For the developmental/mental retardation problem, the average medical cost for a child was 36.58 Bangladesh Taka, and the opportunity cost was 218.23 Bangladesh Taka.

\section{iii. Musculo-skeletal Problems}


For pain of the joints, the average medical cost was 161.86 Bangladesh Taka, and opportunity cost was 1128.57 Bangladesh Taka (Appendix 3). For back pain problems, the average medical expense for a child was 59.33 Bangladesh Taka, and the opportunity cost was 582 Bangladesh Taka. For bone fracture-related problems, the average medical cost was 15,000 Bangladesh Taka, and opportunity cost was 26,000 Bangladesh Taka.

\section{iv. Dermatological Manifestation (Skin Problems)}

For skin rash-related issues, the opportunity cost was 586.66 Bangladesh Taka, and the average medical cost of treatment amounted to 116.66 Bangladesh Taka (Appendix 3). For dermatitis (hot \& irritated skin), the average medical cost was 40 Bangladesh Taka. For absence from work, the average of 300 Bangladesh Taka could not be earned. For the scabies problem, 133.46 Bangladesh Taka was spent by any child as the average, and the opportunity cost was 560 Bangladesh Taka. For cut-related injuries, on average 161.31 Bangladesh Taka was spent, and the opportunity cost was 826 Bangladesh Taka. For bruises, 163.33 Bangladesh Taka was the average expenditure and the opportunity cost was 656.66 Bangladesh Taka.

\section{v. Respiratory Problems}

Regarding coughing-related problems, there was highest average medical cost, and this was 140.73 Bangladesh Taka, and the average opportunity cost was more, i.e. 653.08 Bangladesh Taka. For coughing with blood and shortness of breath, 200 Bangladesh Taka and 1500 Bangladesh Taka were spent, respectively. For absence from work, 204.44 Bangladesh Taka could not be earned when the children endured coughing accompanied by blood, and 900 Bangladesh Taka could not be earned when children experienced shortness of breath (Appendix $3)$.

\section{vi. Gastrointestinal Trace Problems}

The average expenditure for abdominal pain was 153.88 Bangladesh Taka, and the average opportunity cost was 669.44 Bangladesh Taka (Appendix 3). For diarrhoea, a child spent 370 Bangladesh Taka as the average, and for absence from work, it was not possible to earn 1,360.00 Bangladesh Taka. With reference to vomiting, 34.60 Bangladesh Taka was the average expenditure, and the opportunity cost was 45 Bangladesh Taka.

\section{vii. Ocular Manifestations (Eye vision) \& Dental Problems}

For eye vision-related problems, the average expenditure was 160 Bangladesh Taka, and the opportunity cost was 176.66 Bangladesh Taka (Appendix 3). For dental problems, an average expenditure was 186.25 Bangladesh Taka, and 643.75 Bangladesh Taka could not be earned by the children when they were absent from their work.

\section{viii. Wild Animal Hazards}

When having been attacked by stray animals, the average medical service cost was 225 Bangladesh Taka, and the work absence opportunity cost was 1,787.50 Bangladesh Taka, on an average (Appendix 3). Problems caused by mice/rats could mean that the average expenditure was 37.50 Bangladesh Taka. The opportunity cost of this was 100 Bangladesh Taka. 


\subsection{Expected Health Services and Supports}

If waste collection is based on more technology being used, this will reduce health expenditure and $92 \%$ of the children agreed with this (Table 6). The average scale was 4.52 . The researcher wanted to know from the children whether they were conscious about free health services; $48 \%$ stated they did not know or disagreed. $36 \%$ of children said that they were aware or agreed, and the average scale measurement was $1.48 .88 \%$ of the children agreeing that they needed the assistance of health services and the average scale was 4.54. Current health and medical services must be improving; this point was agreed on by $90 \%$ of the children, and the average scale_was 4.36.

Table 6: Respondents' expectation of health facilities

\begin{tabular}{|c|c|c|c|c|c|c|c|c|c|}
\hline \multirow{2}{*}{$\begin{array}{l}\text { Assessment of } \\
\text { personal ability }\end{array}$} & \multicolumn{5}{|c|}{ Observation Scale } & \multirow{2}{*}{$\begin{array}{l}\text { Average } \\
\text { Value of } \\
\text { Scale }\end{array}$} & \multirow{2}{*}{ S.D. } & \multirow{2}{*}{$\begin{array}{c}\text { Agreed } \\
(4 \& 5) \\
\text { Observations } \\
\end{array}$} & \multirow{2}{*}{$\begin{array}{c}\text { Disagreed } \\
(1 \& 2) \\
\text { Observations }\end{array}$} \\
\hline & 1 & 2 & 3 & 4 & 5 & & & & \\
\hline $\begin{array}{l}\text { Medical expenses } \\
\text { will be reduced if } \\
\text { waste collection is } \\
\text { technology-based }\end{array}$ & $0 \%$ & $2 \%$ & $6 \%$ & $30 \%$ & $62 \%$ & 4.52 & 0.71 & $92 \%$ & $2 \%$ \\
\hline $\begin{array}{l}\text { Are you aware of } \\
\text { health facilities, like } \\
\text { free medical service }\end{array}$ & $24 \%$ & $24 \%$ & $16 \%$ & $16 \%$ & $20 \%$ & 2.84 & 1.48 & $36 \%$ & $48 \%$ \\
\hline $\begin{array}{l}\text { You need health } \\
\text { assistance }\end{array}$ & $0 \%$ & $0 \%$ & $12 \%$ & $22 \%$ & $66 \%$ & 4.54 & 0.71 & $88 \%$ & $0 \%$ \\
\hline $\begin{array}{l}\text { Current health and } \\
\text { medical services } \\
\text { need to be improved }\end{array}$ & $0 \%$ & $2 \%$ & $8 \%$ & $44 \%$ & $46 \%$ & 4.36 & 0.72 & $90 \%$ & $2 \%$ \\
\hline
\end{tabular}

The children waste collectors were asked about what their health service expectations; $78 \%$ of them stressed the necessity of free medicine; gender-wise, $46 \%$ boys and $32 \%$ girls believed this. $62 \%$ of the children wanted free medical services, of which, $32 \%$ were boys and $30 \%$ were girls. $30 \%$ of these young waste collectors expected a free medical camp for their treatment, i.e. $14 \%$ were girls and $16 \%$ were boys. $20 \%$ of the children expected to have access to a mobile medical healthcare service, and $16 \%$ of the children expected to have the facility of emergency or fast track booth service.

Table 7: Respondents' expectation of health service

\begin{tabular}{lccccc}
\hline Gender & $\begin{array}{c}\text { Free } \\
\text { medicine }\end{array}$ & $\begin{array}{c}\text { Free medical } \\
\text { camp }\end{array}$ & $\begin{array}{c}\text { First track } \\
\text { booth }\end{array}$ & $\begin{array}{c}\text { Mobile } \\
\text { medical }\end{array}$ & $\begin{array}{c}\text { Free medical } \\
\text { service }\end{array}$ \\
\hline Girl & $16(32 \%)$ & $7(14 \%)$ & $3(6 \%)$ & $4(8 \%)$ & $15(30 \%)$ \\
Boy & $23(46 \%)$ & $8(16 \%)$ & $5(10 \%)$ & $6(12 \%)$ & $16(32 \%)$ \\
\hline Grand Total & $39(78 \%)$ & $15(30 \%)$ & $8(16 \%)$ & $10(20 \%)$ & $31(62 \%)$ \\
\hline
\end{tabular}

\section{Conclusions}

Waste collection is a risky profession and especially for street children. At least $50 \%$ of child waste collectors suffer from injuries, which are generally caused by the conditions of the workplace and medical complications. Due to the nature of the materials that exist in landfills, such as contamination and sharp metal edges, over $50 \%$ of waste collectors suffer from scabies and other skin problems. Results confirm that most respondents wanted free medicine, followed 
by free medical services. They want a healthy life and they dream of much better job options, but there is simply no alternative option. Many of them are engaged in hazardous work, which is harmful to their long-term mental and physical development. Most of the waste pickers suffer from dizziness, followed by fatigue or exertion intolerance caused by tiredness and fever, malnutrition problems, growth retardation, and mental retardation. Moreover, there an increasing number of them are suffering from skin problems; respiratory problems constitute another major concern with significant numbers suffering from chronic coughing. There are cases of gastrointestinal tract problems and eye vision issues. Feeling physical pain on a daily basis is also a common phenomenon for child waste collectors. Most of them report as being affected by arthritis (joint pain), and especially back pain.

The economic cost of health problems that waste collector children have to live with, was estimated by calculating average expenditure and opportunity cost. For general health problems, like fever, fatigue or exertion intolerance, etc., the average expenditure was 51.71 Bangladesh Taka, and the opportunity cost was 305.94 Bangladesh Taka. The highest cost was calculated for bone fractures, the average medical cost being 15,000 Bangladesh Taka, and opportunity cost being 26,000 Bangladesh Taka. One of the most prevalent and frequent health problems to emerge concerned respiratory problems. Coughs resulted in the highest average medical cost (140.73 Bangladesh Taka), and the average opportunity cost was more than all other costs, i.e. 653.08 Bangladesh Taka. In trying to recover from coughing with blood and shortness of breath, 200 Bangladesh Taka and 1500 Bangladesh Taka were spent, respectively.

To improve the health of these children waste collectors, the following recommendations are made and must be implemented urgently. The Directorate-General of Health (DG-Health) which operates under the auspices of the Ministry of Health should establish a community health clinic near major waste centres such as Matuail. It should provide the essential facilities and free heath check-ups should be made available for all children waste collectors. It may be possible to make this affordable by the local authorities working with NGO initiatives to provide what is necessary. The government should make it a priority to request foreign donor support for the introduction of free basic medical facilities for the children. More importantly, the government should establish a minimum age for children entering this hazardous type of work or eliminate it completely by offering alternative work that is safe, according to the ILO guidelines. Donor agencies should be approached and asked if they can help develop an effective strategy for getting the children of Dhaka off the streets and into a much more secure charity that can look after them. Finally, the private sector and particularly the pharmaceutical/healthcare/medical companies should be requested to provide medical and other technical support for this initiative.

\section{Acknowledgement}

The authors are thankful to Dr. Mohammad Obaidul Hoque from Johns Hopkins University, and Mr. Helal Uddin Khan from Parlance Consulting Services Ltd. for their supports and feedbacks to improve the article.

\section{References}

Abdou, M.H.M. 2007. Health Impacts on Workers in Landfill in Jeddah City, Saudi Arabia. Journal of the Egyptian Public Health Association, 82(3-4), 319-329. 
Amegah, A. K., \& Jaakkola, J. J. (2016). Street vending and waste picking in developing countries: a long-standing hazardous occupational activity of the urban poor. International Journal of Occupational and Environmental Health, 22(3), 187192.

Aweng, E.R. and Fatt, C.C. 2014. Survey of potential health risk of rubbish collectors from the garbage dump sites in Kelantan, Malaysia. Asian Journal of Applied Sciences, 2(1), 3644.

Castro, C. L. \& Hunting, K. 2013. Measuring hazardous work and identifying risk factors for non- fatal injuries among children working in Philippine agriculture. American Journal of Industrial Medicine, 56(6), 709-719.

Choi, H. S., Shim, Y. K., Kaye, W. E., \& Ryan, P. B. 2006. Potential residential exposure to toxics release inventory chemicals during pregnancy and childhood brain cancer. Environmental Health Perspectives, 114(7), 1113-1118.

Cointreau, S. 2006. Occupational and Environmental Health Issues of Solid Waste Management, Special Emphasis on Middle and Lower-Income Countries, Working Paper No. 33779, The World Bank.

Cowing, M.J. 2013. Health and Safety Guidelines for Waste Pickers in South Sudan, United Nations Environment Programme, South Sudan.

Dias, S, M, Samson, M. 2016. Informal Economy Monitoring Study Sector Report: Waste Pickers, Women in Informal Employment: Globalizing and Organizing (WIEGO). February 2016.

Direct Initiative for Social \& Health Action, 1996. A Rapid Assessment Survey of the Health and Environmental Impacts of Solid Waste Recycling'. Centre for Occupational \& Environmental Health Society for Participatory Research in Asia, New Delhi, and Centre for Study in Man and Environment, Calcutta.

Edelstein, M. 2018. Contaminated communities: Coping with residential toxic exposure, $2^{\text {nd }}$ ed. New York: Routledge.

Fassa, A.G., Facchini L.A., Dall'Agnol M.M. and Christiani, D.C. 2000. Child labor and health: problems and perspectives. International Journal of Occupational and Environmental Health, 6(1), 55-62.

Goel, K., Ahmad, S., Bansal, R., Parashar, P., Pant, B., \& Goel, P. 2012. The social and occupational health problems of child labor: A challenge the world is facing. Indian Journal of Community Health, 24(1), 53-57.

Guarcello, L., Lyon, S., Rosati, F. 2004. Impact of Working Time on Children's Health, International Labour Organization-International Programme on the Elimination of Child Labour. Geneva: ILO.

Hanchette, C., Zhang, C., \& Schwartz, G. 2018. Ovarian Cancer Incidence in the US and Toxic Emissions from Pulp and Paper Plants: A Geospatial Analysis. International Journal of Occupational and Environmental Health, 15(8), E1619, 1-13.

Haylock, R. G., Gillies, M., Hunter, N., Zhang, W., \& Phillipson, M. 2018. Cancer mortality and incidence following external occupational radiation exposure: an update of the 3rd analysis of the UK national registry for radiation workers. British Journal of Cancer, 119(5), 631-637.

Hossain, M., Alam, M. and Khan, N.A. 2016. Selected Socioeconomic Characteristics of Waste Collector Children in Dhaka City. Development Review, 25, 23-32.

ILO, International Labour Organisation. 1998. Child Labour: Targeting the Intolerable, Conference Report VI (1). Geneva: ILO.

Islam, M.S., Rahman, M.E. and Khatun, R. 2013. Street Children Struggle for Survival Where Protection of Human Resource Development: (A Study on Khulna City, Bangladesh.). International Journal of Scientific \& Technology Research, 2(11), 36-49. 
Kassebaum, N., Kyu, H. H., Zoeckler, L., Olsen, H. E., Thomas, K., Pinho, C., ... \& Hay, S. I. 2017. Child and adolescent health from 1990 to 2015: findings from the global burden of diseases, injuries, and risk factors 2015 study. JAMA Pediatrics, 171(6), 573-592.

Mohammed, E. S., Ewis, A. A. A., \& Mahfouz, E. M. 2014. Child labor in a rural Egyptian community: an epidemiological study. International Journal of Public Health, 59(4), 637-644.

Mukankomeje, R. 2010. Practical Tools on Solid Waste Management of Imidugudu, Small Towns and Cities: Landfill and Composting Facilities, Rwanda Environment Management Authority, Republic of Rwanda Kigali.

Ncube, F., Ncube, E. J., \& Voyi, K. 2017. A systematic critical review of epidemiological studies on public health concerns of municipal solid waste handling. Perspectives in Public Health, 137(2), 102-108.

NSOP, National Statistical Office of the Philippines. 1998. 1995 Survey on Children 5-17 Years Old (SCL). Manila, Philippines.

Posso, A. 2019. The health consequences of hazardous and nonhazardous child labor. Review of Development Economics, 23(2), 619-639.

Ravindra, K., Kaur, K., \& Mor, S. 2016. Occupational exposure to the municipal solid waste workers in Chandigarh, India. Waste Management \& Research, 34(11), 1192-1195.

Ray, M. R., Mukherjee, G., Roychowdhury, S., \& Lahiri, T. (2004). Respiratory and general health impairments of ragpickers in India: a study in Delhi. International Archives of Occupational and Environmental Health, 77(8), 595-598.

Reeve, N. F., Fanshawe, T. R., Keegan, T. J., Stewart, A. G., \& Diggle, P. J. 2013. Spatial analysis of health effects of large industrial incinerators in England, 1998-2008: a study using matched case-control areas. BMJ Open, 3(1), e001847.

Roberts, M. T. 2017. Childhood cancer and spatial analyses of benzene exposure in Texas. Doctoral thesis, Oregon State University.

Rushton, L. 2003. Health hazards and waste management. British Medical Bulletin, 68(1), 183197.

Saifullah, A, Z, A., Md. Tasbirul Islam, M.T. 2016. Municipal solid waste (MSW) management in Dhaka City, Bangladesh, American Journal of Engineering Research, 5(2), 88-100.

Schenck, C. J., Blaauw, P. F., Viljoen, J. M., \& Swart, E. C. (2019). Exploring the Potential Health Risks Faced by Waste Pickers on Landfills in South Africa: A Socio-Ecological Perspective. International Journal of Environmental Research and Public Health, 16(11), E2059.

Singh, S., \& Chokhandre, P. (2015). Assessing the impact of waste picking on musculoskeletal disorders among waste pickers in Mumbai, India: a cross-sectional study. BMJ Open, 5(9), e008474.

Sridevi, P., Modi, M., Lakshmi, M.V.V.C., Kesavarao, L. 2012. A review on integrated solid waste management. International Journal of Engineering Science \& Advanced Technology, 2(5), 1491-1499.

Wang, Y., Hu, J., Lin, W., Wang, N., Li, C., Luo, P., ... \& Liu, Y. 2016. Health risk assessment of migrant workers' exposure to polychlorinated biphenyls in air and dust in an e-waste recycling area in China: indication for a new wealth gap in environmental rights. Environment International, 87, 33-41.

WHO. 1992. Health dimensions of economic reform. [text prepared for the International Forum on Health: A Condition for Economic Development held in Accra, Ghana, on 4 to 6 December 1991]. 


\section{Appendices}

Appendix 1: Demographic and economic profile of waste collector children

\begin{tabular}{|c|c|c|}
\hline Particular & & Total / Average \\
\hline \multicolumn{3}{|l|}{ Gender } \\
\hline & Girl & $20(40 \%)$ \\
\hline & Boy & $30(60 \%)$ \\
\hline & Total & $50(100 \%)$ \\
\hline \multicolumn{3}{|c|}{ Respondent age } \\
\hline & 8-10 Years & $10(20 \%)$ \\
\hline & 11-12 Years & $11(22 \%)$ \\
\hline & 13-15 Years & $29(58 \%)$ \\
\hline \multicolumn{3}{|l|}{ Schooling } \\
\hline & Government & $18(36 \%)$ \\
\hline & NGO & $31(62 \%)$ \\
\hline & No schooling & $1(2 \%)$ \\
\hline \multicolumn{3}{|c|}{$\begin{array}{l}\text { Involvement in waste } \\
\text { collection }\end{array}$} \\
\hline & 1-2 Years & $34(64 \%)$ \\
\hline & 3-4 Years & $15(30 \%)$ \\
\hline & 5 Years & $1(2 \%)$ \\
\hline & Average & 2.12 \\
\hline \multicolumn{3}{|c|}{$\begin{array}{l}\text { Age of starting waste } \\
\text { collection }\end{array}$} \\
\hline & $6-8$ & $7(14 \%)$ \\
\hline & $9-11$ & $22(44 \%)$ \\
\hline & $12-14$ & $21(42 \%)$ \\
\hline & Average & 10.54 \\
\hline \multicolumn{3}{|c|}{ Food collection from waste } \\
\hline & Girl & $8(16 \%)$ \\
\hline & Boy & $5(10 \%)$ \\
\hline & No collector & $37(74 \%)$ \\
\hline \multicolumn{3}{|l|}{ House } \\
\hline & Brick & $7(14 \%)$ \\
\hline & Tin Shed & $32(64 \%)$ \\
\hline & Mixed & $11(22 \%)$ \\
\hline \multicolumn{3}{|l|}{ House rent } \\
\hline & 1100-1500 Bangladesh Taka & $8(16 \%)$ \\
\hline & 1600-2500 Bangladesh Taka & $30(60 \%)$ \\
\hline & 2600-3500 Bangladesh Taka & $12(24 \%)$ \\
\hline & Average & 2,213 \\
\hline \multicolumn{3}{|c|}{$\begin{array}{l}\text { Household's earning } \\
\text { members }\end{array}$} \\
\hline & 2 Members & $13(26 \%)$ \\
\hline & 3 Members & $20(40 \%)$ \\
\hline & 4 Members & $17(34 \%)$ \\
\hline & Average & 3.08 \\
\hline \multicolumn{3}{|c|}{ Household's economic status } \\
\hline & A child's average daily income from waste & 78.7 \\
\hline & $\begin{array}{l}\text { A household's average daily income from } \\
\text { waste }\end{array}$ & 437.8 \\
\hline & $\begin{array}{l}\text { A household's average daily income from } \\
\text { others }\end{array}$ & 138 \\
\hline & A household's total income average & 573.8 \\
\hline & Per person daily income in a house & 137.95 \\
\hline & A household's below poverty line & $16 \%$ \\
\hline & A household's average saving & 2870 \\
\hline & A household's average borrowing & 1696 \\
\hline
\end{tabular}


Appendix 2: Health problems of children waste collectors

\begin{tabular}{|c|c|c|c|c|}
\hline Disease & $\begin{array}{l}\text { Total Affected } \\
\text { Children }\end{array}$ & $\begin{array}{c}\text { Affected } \\
\text { Several Times } \\
\text { or Chronic }\end{array}$ & $\begin{array}{c}\text { Affected } \\
\text { Children's } \\
\text { Average } \\
\text { Days of } \\
\text { Suffering } \\
\end{array}$ & $\begin{array}{l}\text { Treatment } \\
\text { Received by } \\
\text { Affected } \\
\text { Children }\end{array}$ \\
\hline \multicolumn{5}{|l|}{ Common Health Problems } \\
\hline Fever & $32(64 \%)$ & $27(54 \%)$ & 43.59 & $31.25 \%$ \\
\hline Fatigue/ exertion intolerance due to tiredness & $34(68 \%)$ & $30(60 \%)$ & 25.88 & $17.65 \%$ \\
\hline Dizziness & $43(86 \%)$ & $32(64 \%)$ & 22.59 & $9.30 \%$ \\
\hline \multicolumn{5}{|l|}{ Growth and Developmental Problems } \\
\hline Growth retardation & $32(64 \%)$ & 0 & 0 & $28.12 \%$ \\
\hline Developmental /Mental retardation & $34(68 \%)$ & 0 & 0 & $23.53 \%$ \\
\hline \multicolumn{5}{|l|}{ Musculo-skeletal problems } \\
\hline Arthritis (joint pain) & $7(14 \%)$ & $6(12 \%)$ & 17.43 & $85.71 \%$ \\
\hline Back pain & $15(30 \%)$ & $10(20 \%)$ & 15.26 & $73.33 \%$ \\
\hline Bone fracture & $1(2 \%)$ & 0 & 90 & $100 \%$ \\
\hline \multicolumn{5}{|l|}{ Dermatological Manifestations } \\
\hline Skin rash & $6(12 \%)$ & $3(6 \%)$ & 28.33 & $66.66 \%$ \\
\hline Dermatitis (hot \& irritated skin) & $1(2 \%)$ & $1(2 \%)$ & 15 & $16.66 \%$ \\
\hline Scabies & $26(52 \%)$ & $18(36 \%)$ & 24.57 & $23.07 \%$ \\
\hline Injuries from cuts & $25(50 \%)$ & 0 & 13.32 & $96 \%$ \\
\hline Bruise & $3(6 \%)$ & 0 & 20 & $100 \%$ \\
\hline \multicolumn{5}{|l|}{ Respiratory Problems } \\
\hline Cough & $34(68 \%)$ & $30(60 \%)$ & 17.29 & $82.35 \%$ \\
\hline Haemoptysis (coughing with blood) & $1(2 \%)$ & 0 & 20 & $100 \%$ \\
\hline Dyspnoea (shortness of breath) & $9(18 \%)$ & $7(14 \%)$ & 25.55 & $77.77 \%$ \\
\hline \multicolumn{5}{|l|}{ Gastrointestinal Tract Problems } \\
\hline Abdominal pain & $18(36 \%)$ & $15(30 \%)$ & 16.05 & $94.44 \%$ \\
\hline Diarrhoea & $5(10 \%)$ & $4(8 \%)$ & 32 & $80 \%$ \\
\hline Vomiting & $15(30 \%)$ & $12(24 \%)$ & 30.26 & $13.33 \%$ \\
\hline \multicolumn{5}{|l|}{ Ocular Manifestations \& Dental Problems } \\
\hline Eye vision problems & $3(6 \%)$ & $1(2 \%)$ & 18.33 & $66.66 \%$ \\
\hline Dental problems & $8(16 \%)$ & $4(8 \%)$ & 14.5 & $100 \%$ \\
\hline \multicolumn{5}{|l|}{ Animals and Others } \\
\hline Stray animals & $4(8 \%)$ & 0 & 19.75 & $100 \%$ \\
\hline Parasites (i.e. worms) & $2(4 \%)$ & 0 & 0 & $100 \%$ \\
\hline Head lice & $1(2 \%)$ & $1(2 \%)$ & 40 & $100 \%$ \\
\hline Mice/rats & $4(8 \%)$ & 0 & 4.75 & $8 \%$ \\
\hline
\end{tabular}


Appendix 3: Estimated cost of health problems of waste collector children

\begin{tabular}{|c|c|c|c|c|}
\hline Disease & $\begin{array}{l}\text { Received } \\
\text { free } \\
\text { Doctor } \\
\text { Service }\end{array}$ & $\begin{array}{l}\text { Received } \\
\text { free } \\
\text { Medicine }\end{array}$ & $\begin{array}{c}\text { Average } \\
\text { expenditures } \\
\text { (BDT) by } \\
\text { Affected } \\
\text { Children } \\
\end{array}$ & $\begin{array}{c}\text { Opportunity } \\
\text { Cost (BDT) } \\
\text { of Affected } \\
\text { Children }\end{array}$ \\
\hline \multicolumn{5}{|l|}{ Common Health Problems } \\
\hline Fever & $34.38 \%$ & $15.62 \%$ & 51.71 & 305.94 \\
\hline Fatigue or Exertion intolerance due to tiredness & $17.65 \%$ & $8.82 \%$ & 24.26 & 177.5 \\
\hline Dizziness & $6.98 \%$ & 0 & 23.12 & 99.65 \\
\hline \multicolumn{5}{|l|}{ Growth and Developmental Problems } \\
\hline Growth retardation & $15.62 \%$ & $9.37 \%$ & 33.75 & 227.65 \\
\hline Developmental /Mental retardation & $20.59 \%$ & $8.82 \%$ & 36.58 & 218.23 \\
\hline \multicolumn{5}{|l|}{ Musculo-skeletal Problems } \\
\hline Arthritis (joint pain) & $14.28 \%$ & 0 & 161.86 & 1128.57 \\
\hline Back pain & $53.33 \%$ & $20 \%$ & 59.33 & 582 \\
\hline Bone fracture & 0 & 0 & 15000 & 26000 \\
\hline \multicolumn{5}{|l|}{ Dermatological Manifestations } \\
\hline Skin rash & $33.33 \%$ & $16.66 \%$ & 116.66 & 586.66 \\
\hline Dermatitis (hot \& irritated skin) & $100 \%$ & 0 & 40 & 300 \\
\hline Scabies & $53.85 \%$ & $15.38 \%$ & 133.46 & 560 \\
\hline Injuries from cuts & $32 \%$ & 0 & 131.6 & 826 \\
\hline Bruise & 0 & 0 & 163.33 & 656.66 \\
\hline \multicolumn{5}{|l|}{ Respiratory Problems } \\
\hline Cough & $26.47 \%$ & $32.35 \%$ & 140.73 & 653.08 \\
\hline Haemoptysis (coughing with blood) & 0 & 0 & 200 & 1500 \\
\hline Dyspnoea (shortness of breath) & 0 & 0 & 204.44 & 900 \\
\hline \multicolumn{5}{|l|}{ Gastrointestinal Tract Problems } \\
\hline Abdominal pain & $22.22 \%$ & 0 & 153.88 & 669.44 \\
\hline Diarrhoea & 0 & 0 & 370 & 1360 \\
\hline Vomiting & 0 & 0 & 34.60 & 45 \\
\hline \multicolumn{5}{|l|}{ Ocular Manifestations \& Dental Problems } \\
\hline Eye vision problems & $33.33 \%$ & 0 & 160 & 176.66 \\
\hline Dental problems & 0 & 0 & 186.25 & 643.75 \\
\hline \multicolumn{5}{|l|}{ Animals and Others } \\
\hline Stray animals & $100 \%$ & $100 \%$ & 225 & 1787.50 \\
\hline Parasites (i.e. worms) & 0 & 0 & 25 & 25 \\
\hline Head lice & 0 & 0 & 40 & 40 \\
\hline Mice/rats & $25 \%$ & 0 & 37.50 & 100 \\
\hline
\end{tabular}

* The imputed value is calculated as the average (number of days away from the job due to suffering and not able to earn a daily income) throughout the six-month period. 


\section{Author's Biography:}

Dr. Md. Mahmudul Alam is a Senior Lecturer of Finance at Universiti Utara Malaysia, and a Research Fellow at Frankfurt School of Finance \& Management, University Technology MARA, and International Islamic University Chittagong. He obtained his PhD and Master's degrees in Environment and Development (Finance \& Economics) from National University of Malaysia. He has many publications, including 100 plus articles in refereed journals and five books/monographs. He has presented more than 70 articles at international conferences. He is recognized by BDRC as one of the "Top Bangladesh Development Researchers of the Millennium". His research areas include sustainable finance, sustainable development, ecological economics, financial economics and Islamic economics.

Mohammad Saeed Hossain is currently an assistance officer in EBL Securities Ltd, a subsidiary of Eastern Bank Ltd in Bangladesh. He is also a founder and secretary general of Good Sense Foundation, Dhaka, Bangladesh. He received his Master's degrees in Development Studies from East West University and Management from Dhaka Collage under National University, Bangladesh. He is actively involved in research and development activities. His concern areas include socioeconomic study, capital market research, stock technical analysis, investor behavior, sharia index, etc.

Dr Nurul Islam is a medical doctor and working as a post-graduate trainee at Dhaka Medical College \& Hospital, Bangladesh. $\mathrm{He}$ is also working as an assistant laparoscopic cholecystectomy surgeon in a private hospital. He completed his graduation (MBBS) from Delta Medical College under University of Dhaka in 2017. His research areas are molecular genetics and cardiovascular surgery.

Dr Md. Wahid Murad is currently a lecturer in economics and business at the University of South Australia. Previously, he worked at the University of Adelaide, South Australia and University of Malaysia Terengganu, Multimedia University in Malaysia in various positions, including lecturer, senior lecturer, head of economics discipline and an Associate Dean. Dr Murad has nearly 16 years of teaching experience and has been a researcher for over 21 years in Australia, and Malaysia. He has taught at undergraduate and postgraduate levels and supervised HDR students to completion. He has published a book, chapters in several books, and research articles in nearly 50 scholarly international journals in the areas of economic globalization, socioeconomics, tourism economics, environment, and development economics.

Professor Dr. Niaz Ahmed Khan has a rich blend of academic and practicing development management experiences. He is a professor of the department of development studies at University of Dhaka, senior academic advisor and coordinator at BRAC Institute of Governance and Development, and executive director of Centre for Resources and Development Research. He was a South Asian fellow at Queen Elizabeth House in University of Oxford, research fellow at University of Wales, professor of public administration at University of Chittagong, and Asia research fellow at Asian Institute of Technology. He also has experiences of working with International Union for Conservation Nature, World Bank, United Nations, Asian Development Bank, United States Agency for International Development, Swansea Bay Racial Equality Council, and Government of Bangladesh. He holds a Ph.D. with distinction from the University of Wales. He has more than 160 articles and book chapters to national and international refereed journals and books. 